\title{
Front Matter: Volume 11361
}

, "Front Matter: Volume 11361," Proc. SPIE 11361, Biophotonics in Point-ofCare, 1136101 (20 April 2020); doi: 10.1117/12.2571883

SPIE. Event: SPIE Photonics Europe, 2020, Online Only 


\title{
PROCEEDINGS OF SPIE
}

\section{Biophotonics in Point-of-Care}

\author{
Michael T. Canva \\ Ambra Giannetti \\ Hatice Altug \\ Julien Moreau \\ Editors \\ 6-10 April 2020 \\ Online Only, France \\ Sponsored by \\ SPIE \\ Cosponsored by \\ City of Strasbourg (France) \\ Eurometropole (France) \\ CNRS (France) \\ Région Grand Est (France) \\ iCube (France) \\ Université de Strasbourg (France) \\ Cooperating Organisations \\ Photonics 21 (Germany) \\ EOS-European Optical Society (Germany) \\ Photonics Public Private Partnership (Belgium) \\ Photonics France (France) \\ Published by \\ SPIE
}

Volume 11361 
The papers in this volume were part of the technical conference cited on the cover and title page. Papers were selected and subject to review by the editors and conference program committee. Some conference presentations may not be available for publication. Additional papers and presentation recordings may be available online in the SPIE Digital Library at SPIEDigitalLibrary.org.

The papers reflect the work and thoughts of the authors and are published herein as submitted. The publisher is not responsible for the validity of the information or for any outcomes resulting from reliance thereon.

Please use the following format to cite material from these proceedings:

Author(s), "Title of Paper," in Biophotonics in Point-of-Care, edited by Michael T. Canva, Ambra Giannetti, Hatice Altug, Julien Moreau, Proceedings of SPIE Vol. 11361 (SPIE, Bellingham, WA, 2020) Seven-digit Article CID Number.

ISSN: 0277-786X

ISSN: 1996-756X (electronic)

ISBN: 9781510634947

ISBN: 9781510634954 (electronic)

Published by

SPIE

P.O. Box 10, Bellingham, Washington 98227-0010 USA

Telephone +1 3606763290 (Pacific Time) · Fax +1 3606471445

SPIE.org

Copyright (C) 2020, Society of Photo-Optical Instrumentation Engineers.

Copying of material in this book for internal or personal use, or for the internal or personal use of specific clients, beyond the fair use provisions granted by the U.S. Copyright Law is authorized by SPIE subject to payment of copying fees. The Transactional Reporting Service base fee for this volume is $\$ 21.00$ per article (or portion thereof), which should be paid directly to the Copyright Clearance Center (CCC), 222 Rosewood Drive, Danvers, MA 01923. Payment may also be made electronically through CCC Online at copyright.com. Other copying for republication, resale, advertising or promotion, or any form of systematic or multiple reproduction of any material in this book is prohibited except with permission in writing from the publisher. The CCC fee code is 0277$786 \mathrm{X} / 20 / \$ 21.00$.

Printed in the United States of America by Curran Associates, Inc., under license from SPIE.

Publication of record for individual papers is online in the SPIE Digital Library.

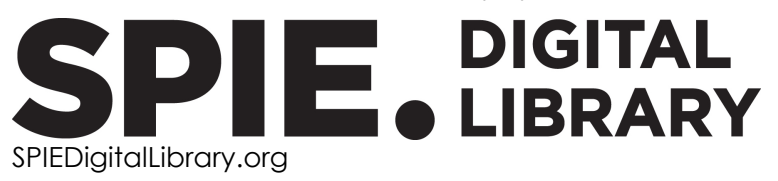

Paper Numbering: Proceedings of SPIE follow an e-First publication model. A unique citation identifier (CID) number is assigned to each article at the time of publication. Utilization of CIDs allows articles to be fully citable as soon as they are published online, and connects the same identifier to all online and print versions of the publication. SPIE uses a seven-digit CID article numbering system structured as follows:

- The first five digits correspond to the SPIE volume number.

- The last two digits indicate publication order within the volume using a Base 36 numbering system employing both numerals and letters. These two-number sets start with 00, 01, 02, 03, 04, $05,06,07,08,09,0 A, 0 B \ldots$. OZ, followed by 10-1Z, 20-2Z, etc. The CID Number appears on each page of the manuscript. 


\title{
Contents
}

\author{
$\checkmark \quad$ Authors \\ vii Conference Committee
}

ENABLING TECHNOLOGIES FOR INSTRUMENTATION AND LAB-ON-A-CHIP I

1136109 Biofunctionalization strategies for optical fiber grating immunosensors (Invited Paper) [1 1361-9]

11361 OA 3D printing of multifunctional optofluidic systems for high-sensitive detection of pathological biomarkers in liquid biopsies [11361-10]

ENABLING TECHNOLOGIES FOR INSTRUMENTATION AND LAB-ON-A-CHIP II

$113610 \mathrm{C}$ Non-contact PPG measurement system incorporating image analyzed photoplethysmogram signals and deep learning algorithms [11361-12]

APPLICATIONS OF POCT

11361 0J Toward a SPR imaging in situ system to detect marine biotoxin [11361-21]

11361 OL Circulating cancer cell detection using an optical fiber aptasensor [11361-23]

\section{POSTER SESSION}

11361 OP Compact multichannel spectroscopic label-free biosensor platform for plant diseases point-ofcare testing (POCT) [11361-26]

11361 OW Periodontal probe based on the fluorescent fiber position sensor [11361-33]

$113610 Z$ Wearable multi-sensor for plant monitoring, based on fluorescent fibers [11361-36] 
Proc. of SPIE Vol. 11361 1136101-4

\section{Downloaded From: https://www.spiedigitallibrary.org/conference-proceedings-of-spie on 26 Apr 2023
Terms of Use: https://www.spiedigitallibrary.org/terms-of-use}




\section{Authors}

Numbers in the index correspond to the last two digits of the seven-digit citation identifier (CID) article numbering system used in Proceedings of SPIE. The first five digits reflect the volume number. Base 36 numbering is employed for the last two digits and indicates the order of articles within the volume. Numbers start with 00, 01, 02, 03, 04, 05, 06, 07, 08, 09, OA, OB...0Z, followed by 10-1Z, 20-2Z, etc.

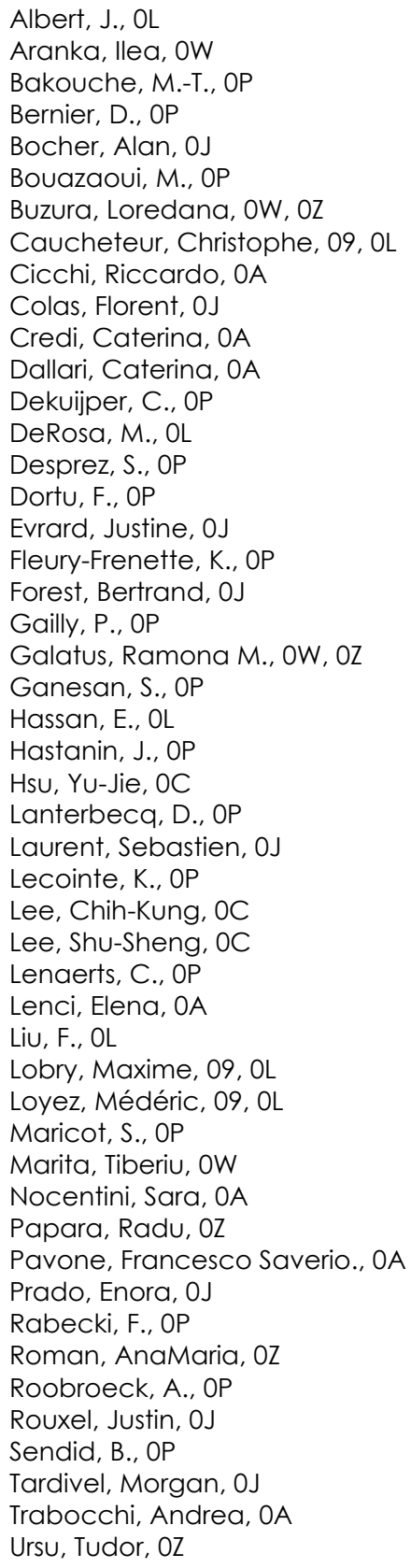

Vilcot, J.-P., OP

Wang, Chun-Hsiung, $\mathrm{OC}$

Wattiez, Ruddy, 09, OL

Wiersma, Diederik, OA

Willmore, W., OL

Wu, Wen-Jong, OC 
Proc. of SPIE Vol. 11361 1136101-6

\section{Downloaded From: https://www.spiedigitallibrary.org/conference-proceedings-of-spie on 26 Apr 2023
Terms of Use: https://www.spiedigitallibrary.org/terms-of-use}




\title{
Conference Committee
}

\author{
Symposium Chairs
}

Francis Berghmans, Vrije Universiteit Brussel (Belgium)

Thierry Georges, Oxxius SA (France)

Paul C. Montgomery, Université de Strasbourg (France)

Lluis Torner, ICFO Barcelona (Spain)

Conference Chairs

Michael T. Canva, CNRS (France)

Ambra Giannetti, Istituto di Fisica Applicata "Nello Carrara"-CNR (Italy)

Hatice Altug, Ecole Polytechnique Fédérale de Lausanne

(Switzerland)

Julien Moreau, Institut d'Optique Graduate School (France)

Conference Programme Committee

Francis Berghmans, Vrije Universiteit Brussel (Belgium)

Jakub Dostálek, AIT Austrian Institute of Technology GmbH (Austria)

Laura M. Lechuga Gómez, Institut Català de Nanociència i

Nanotecnologia (Spain)

Thierry Livache, Aryballe Technologies (France)

Boris Mizaikoff, Universität Ulm (Germany)

Genni Testa, IREA-CNR (Italy)

Nathalie Vermeulen, Vrije Universiteit Brussel (Belgium)

Bruno Wacogne, Femto-st (France)

Session Chairs

1 Photonic and Nanophotonic Sensing Means I

Michael T. Canva, Laboratoire Charles Fabry (Canada)

2 Photonic and Nanophotonic Sensing Means II

Julien Moreau, Institut d'Optique Graduate School (France)

3 Enabling Technologies for Instrumentation and Lab-on-a-Chip I

Ambra Giannetti, Istituto di Fisica Applicata "Nello Carrara" (Italy)

4 Enabling Technologies for Instrumentation and Lab-on-a-Chip II

Hatice Altug, Ecole Polytechnique Fédérale de Lausanne

(Switzerland) 
5 Enabling Technologies for Instrumentation and Lab-on-a-Chip III Julien Moreau, Institut d'Optique Graduate School (France)

6 Applications of POCT

Ambra Giannetti, Istituto di Fisica Applicata "Nello Carrara" (Italy) 